\title{
Behavioural study of two Hydrothermal crustacean decapods: Mirocaris fortunata and Segonzacia mesatlantica, from the lucky strike vent field (mid-Atlantic ridge)
}

\author{
Matabos Marjolaine ${ }^{1,{ }^{*}}$, Cuvelier Daphne ${ }^{1}$, Brouard Johan ${ }^{1}$, Shillito B. ${ }^{2,3}$, Ravaux J. ${ }^{2,3}$, Zbinden M. ${ }^{2,3}$, \\ Barthelemy D. ${ }^{4}$, Sarradin Pierre-Marie ${ }^{1}$, Sarrazin Jozée ${ }^{1}$
}

${ }^{1}$ Institut Carnot Ifremer EDROME, Centre de Bretagne, REM/EEP, Laboratoire Environnement Profond, F-8 29280 Plouzané, France

${ }^{2}$ Sorbonne Universités, UPMC Univ Paris 06, UMR CNRS 7208, Adaptations aux Milieux Extrêmes, F75005, Paris, France

${ }^{3}$ MNHN, UMR CNRS 7208, Biologie des ORganismes et Ecosystèmes Aquatiques (BOREA), F-75005, Paris, France

${ }^{4}$ Océanopolis, Port de plaisance du Moulin Blanc, BP 91039, 29210 Brest Cedex 1, France

* Corresponding author : Marjolaine Matabos, Tel.: +33 (0)29 2243 05. ;

email address : Marjolaine.Matabos@ifremer.fr

\begin{abstract}
:
Identifying the factors driving community dynamics in hydrothermal vent communities, and in particular biological interactions, is challenged by our ability to make direct observations and the difficulty to conduct experiments in those remote ecosystems. As a result, we have very limited knowledge on species' behaviour and interactions in these communities and how they in turn influence community dynamics. Interactions such as competition or predation significantly affect community structure in vent communities, and video time-series have successfully been used to gain insights in biological interactions and species behaviour, including responses to short-term changes in temperature or feeding strategies. In this study, we combined in situ and ex situ approaches to characterize the behaviour and interactions among two key species encountered along the Mid-Atlantic Ridge (MAR): the shrimp Mirocaris fortunata and the crab Segonzacia mesatlantica. In situ, species small-scale distribution, interactions and behaviour were studied using the TEMPO observatory module deployed on the seafloor at the base of the active Eiffel Tower edifice in the Lucky Strike vent field as part of the EMSO-Açores MoMAR observatory. TEMPO sampled 2 min of video four times a day from July 2011 to April 2012. One week of observations per month was used for 'long-term' variations, and a full video data set was analysed for January 2012. In addition, observations of crab and shrimp individuals maintained for the first time under controlled conditions in atmospheric pressure (classic tank) and pressurized (AbyssBox) aquaria allowed better characterisation and description of the different types of behaviour and interactions observed in nature. While the identified in situ spatial distribution pattern was stable over the nine months, both species displayed a significant preference for mussel bed and anhydrite substrata, and preferentially occupied the area located directly in the fluid flow axis. The aggregation behaviour of $M$. fortunata resulted in the occurrence of numerous intraspecific interactions mainly involving the use of two pairs of sensory organs (antenna/antennule) and fleeing behaviours
\end{abstract}


when in contact or close to individuals of $S$. mesatlantica. The higher level of passiveness observed in the ex situ artificial environment compared to the in situ environment was attributed to the lack of stimulation related to low densities of congeners and/or of sympatric species compared to the natural environment and the absence of continuous food supply, as both species displayed a significant higher level of activity during feeding time. This result emphasizes the role of food supply as a driver of species distribution and behaviour. Direct in situ observations using cameras deployed on deep-sea observatories, combined with experimental set-up in pressurized aquaria, will help investigators understand the factors influencing community dynamics and species biology at vents as well as their underlying mechanisms.

Keywords: AbyssBox, Biological interactions, Deep-sea observatory, Eiffel Tower edifice, Feeding behaviour, Experimental research, Video imagery, Time series, Lucky Strike, Mid-Atlantic Ridge, $37^{\circ} 17^{\prime} \mathrm{N}, 32^{\circ} 16.3^{\prime} \mathrm{W}$ 


\section{Introduction}

Hydrothermal vents are located along mid-ocean ridges, back-arc basins and volcanic seamounts where seawater percolates through the thin oceanic crust and is ejected as hot fluids with high concentrations of reduced sulphur, methane and metals (e.g., iron, copper and zinc). They host highly productive communities fueled primarily by chemosynthetic microbial production dependent on ephemeral fluxes of sulphide- and methane-rich emissions (Tunnicliffe, 1991). The mixing of these fluids with seawater causes steep environmental gradients resulting in small-scale temporal (e.g., minute) and spatial (e.g., cm) physicochemical variations (Johnson et al., 1986), which can create a large number of microenvironments on a single edifice (Sarradin et al., 1998; Sarrazin et al., 1999; Luther et al., 2012). To date most of the knowledge about the functioning of these remote ecosystems results from, at best, yearly sea-going cruises. Consequently, little is known about the temporal and small spatial variations in community structure and how organisms respond to changes in local environmental conditions (Cuvelier et al., 2014; Sarrazin et al., 2014).

Most ecological studies emphasize the importance of the high spatial variability of abiotic factors in terms of fluid flow, temperature and chemical composition, and the physical structure of the mineral substrate in controlling benthic species distribution within a single vent structure (Hessler et al., 1988; Tunnicliffe, 1991; Sarrazin et al., 1997, 2002; Shank et al., 1998; Cuvelier et al., 2009). Nevertheless, the mechanisms by which environmental conditions shape vent communities appear quite complex. According to the correspondence between physico-chemical gradients and faunal zonation, physiological tolerance and nutritional requirements were suggested to be the main direct pathways of environmental control (Desbruyères et al., 1998; Fisher, 1998; Lee, 2003; Bates et al., 2005). Environmental conditions can also indirectly influence species distribution by controlling biological interactions within and among species, including predation (Micheli et al., 2002; Sancho et 
al., 2005), competition and species behaviour (Bates et al., 2013). While biotic interactions can act independently of physico-chemical factors within a habitat type (Mullineaux et al., 2000; Govenar et al., 2005; Lenihan et al., 2008), those processes seem to vary along a gradient of flow intensity with facilitation processes (e.g., providing refuge for new recruits) occurring at the periphery of vents and inhibition processes (e.g., grazing of new recruits, competition for space) dominating high diffuse flow areas (Mullineaux et al., 2003). Finally, variations in fluid flow can significantly control population dynamics including growth (Schöne and Giere, 2005) and reproduction (Copley et al., 2003; Kelly and Metaxas, 2007; Sheader and Van Dover, 2007; Nye et al., 2013; Sheader and Van Dover, 2007), but studies are scarce. Indeed, the lack of direct observations and long time-series (Glover et al., 2010) combined with the difficulty to maintain vent animals in aquaria led to a major gap in our current knowledge of species auto-ecology (or species ecology; i.e., relationship between a single species and its environment).

In situ imagery is a good means to investigate species spatial distribution because it provides access to living species in their natural habitats and has been widely used since the discovery of hydrothermal vent communities (Hessler et al. 1985; Tunnicliffe and Juniper, 1990; Grehan and Juniper, 1996; Copley et al., 1997, 2007; Sarrazin et al., 1997; Shank et al., 1998; Cuvelier et al., 2009, 2011, 2012). In addition, imagery methods mitigate environmental impact and disturbance related to sampling (Tunnicliffe, 1990). With the development of deep-sea observatories, we can now describe patterns and the underlying processes at sub-annual scales using video cameras (Cuvelier et al., 2014; Sarrazin et al., 2014). They provide high-resolution video time-series that help to document small-scale assemblage dynamics and to study organisms' growth, faunal succession, biological interactions and species/communities' responses to environmental changes (Juniper et al., 2007; Sarrazin et al., 2007). Continuous video data have already been successfully used to 
assess species behaviour (Chevaldonné and Jollivet, 1993; Bates et al., 2005; Grelon et al., 2006; Robert et al., 2012; Tunnicliffe et al., 2013) but those studies are restricted to polychaetes and gastropods and are limited in time. In this context, an ecological module called TEMPO was developed to specifically study long-term deep-sea communities' dynamics at hydrothermal vents (Sarrazin et al., 2007; Auffret et al., 2009) and was deployed in 2010 on the Mid-Atlantic Ridge within the Lucky Strike vent field (Cannat et al., 2011; Colaço et al., 2011).

Two main faunal assemblages characterize the Lucky Strike vent field: one dominated by the vent mussel Bathymodiolus azoricus and the other dominated by the alvinocaridid shrimp Mirocaris fortunata (Desbruyères et al., 2000, 2001). These assemblages spatially segregate along a gradient of fluid flow intensity with shrimp-dominated communities and large mussels colonizing warmer habitats, while small mussel communities colonize cooler microhabitats (Cuvelier et al., 2009; De Busserolles et al., 2009; Sarrazin et al. this issue). The community found on Eiffel Tower corresponds to a climax community following a model of successional patterns using 14 years of data (Cuvelier et al., 2011b). In this model, environmental conditions did not account for all the successional patterns described, and the authors suggested hydrodynamic conditions, larval settlement and biotic interactions as additional influencing factors, thus uncovering the methodological limitations related to punctual sampling and video transects (Cuvelier et al., 2011b).

The objective of this study is to understand the behavioural responses and conspecific interactions of two of the main visible species encountered at Lucky Strike, the alvinocaridid Mirocaris fortunata (Martin and Christiansen, 1995) and the bythograeid crab Segonzacia mesatlantica (Williams, 1988), in relation to the environment, and thus infer how their behaviour can influence community structure and composition. For this, direct in situ 
observations using the TEMPO observatory module were compared to observations conducted under experimental conditions, using the Abyssbox, a unique high-pressure set-up launched in 2012 (see Shillito et al., this issue for details).

\section{Material and methods}

\subsection{In situ observations}

\subsubsection{The study site and the MoMAR observatory}

The EMSO-Açores MoMAR observatory was deployed in 2010 on the Lucky Strike (LS) vent field of the Mid-Atlantic Ridge (MAR, Cannat et al., 2011, Fig. 1). Located at the summit of a volcano, LS is one of the largest fields encountered at the MAR, extending over more than $1 \mathrm{~km}^{2}$ (Langmuir et al., 1997). A central lava lake is surrounded by more than 20 active and inactive vent sites (Fouquet et al., 1995; Cannat et al., 1999; Ondréas et al., 2009). This field was chosen by the scientific community for long-term seafloor observation to study the interactions between magmatic, tectonic, hydrothermal, and biological processes at midocean ridges (Cannat et al., 2011; Colaço et al., 2011). The EMSO-Açores MoMAR observatory infrastructure is a unique prototype, comprised of two seafloor monitoring nodes (SEAMON east and west) with their connected instruments and a transmission buoy that communicates acoustically with the seafloor stations and relays data via satellite every 6 hours to the Ifremer-hosted EMSO data center (Blandin et al., 2010). The SEAMON stations provide power, communication and data storage to a set of connected sensors (Blandin and Rolin, 2005).

In the south-eastern part of the LS field, the $11 \mathrm{~m}$ high Eiffel Tower active edifice (Fig. 1) is one of the most studied vent sites and has been the subject of numerous ecological studies (Desbruyères et al., 2001; Cuvelier et al., 2009, 2011a, b; , 2014; De Busserolles et al., 
2009; Ivanenko et al., 2011; Sarrazin et al., 2014). It was selected for the deployment of the ecological node SEAMON east. The latest version of TEMPO was deployed in 2010 at the southern base of the edifice with the remotely operated vehicle (ROV) Victor6000 and has been reconditioned every year since. The module allows the direct observation of a Bathymodiolus azoricus mussel assemblage and provides data on associated temperature, oxygen and iron concentrations (Sarrazin et al., 2014). The data analyzed in this study were collected from July 19, 2011 to July 14, 2012. The module is built around an aluminum frame equipped with a handle and two adjustable feet, and is composed of an autonomous video camera (720 x 576 pixels) and two 35 W LED projectors, both protected by an anti-fouling system based on local chlorination (Sarrazin et al., 2007), a CHEMINI Fe in situ analyser measuring total dissolved iron concentrations (Vuillemin et al., 2009), an Aanderaa optode (oxygen probe) and two autonomous temperature probes (NKE, ST6000). The camera recorded 2-minute video sequences four times a day (i.e., 0 h, 6 h, $12 \mathrm{~h}$ and $18 \mathrm{~h}$ UTC), but due to technical issues video recordings stopped in April 2012. The CHEMINI Fe analyser failed over this deployment but oxygen and temperature measurements were acquired during the full period.

\subsubsection{TEMPO image analyses}

For the analysis of long-term temporal variability, one week of video was analysed every month (from the $20^{\text {th }}$ to $26^{\text {th }}$ of each month) from July 2011 to March 2012 (referred as discontinuous data). In addition, in order to characterize short-term variability, the full set of video footage was analysed for the month of January 2012 (referred as continuous data). The full data set included 348 videos sequences, 28 of which could not be read, resulting in a total of 320 sequences to analyse. The nine-week data represented 233 video recordings, or $7.75 \mathrm{~h}$ of images, and the one-month data, 113 video recordings (26 overlapping with the 
discontinuous data), i.e., $3.75 \mathrm{~h}$ of images (Table 1). The image was treated as a twodimensional plane, and the total surface area (adding up to $11384 \mathrm{~cm}^{2}$ ) filmed by the camera was estimated using the size of the oxygen sensor green plate as a scale $(3.5 \mathrm{~cm}$ length, Fig. 2). This extrapolation generated a bias in distance estimation, and only relative changes in species distributions were considered. Two different grids of known-size cells provided guidance for surface, animal density and fluid flow velocity calculations. A first grid of $4 \times 4$ (30.8 cm x $23.1 \mathrm{~cm} / \mathrm{cell})$ was applied to video snapshot images using Adobe Photoshop CS3 (C) in order to count the organisms and assess the surface covered by each type of substratum that could be consistently visually defined, including both abiotic substratum and faunal assemblages. The substrata identified were mussel beds, anhydrites, bare substratum, bacterial mats, anemones, the probe area and unknown surfaces (Fig. 2). Total abundances as well as abundances per substratum type and within the fluid flow area were calculated manually using both snapshot counts and video images. A finer $10 \times 10 \operatorname{grid}(12.32 \mathrm{~cm}$ x $9.24 \mathrm{~cm} / \mathrm{cell})$ was applied on video images using AVS video editor (c) to estimate fluid flow velocity. The flow speed was assessed by tracking at least three particles per video sequence across the grid cells, and averaging their displacement speed (see protocol in Sarrazin et al., 2009). Finally, different ethological indexes were defined to characterize species behaviour (level of activity) and interactions (type of activity or contact, i.e., predation, aggressiveness, reproduction) and are presented in Table 2.

\subsection{Ex situ observations}

\subsubsection{Experimental setup}

Since 2012, the Océanopolis aquarium located in Brest, France, has been maintaining alive Mirocaris fortunata and Segonzacia mesatlantica organisms collected during the different expeditions on the LS vent field (see Shillito et al. this issue for details). During our 
experiment two experimental set-ups were used. (1) A 'classic' tank at atmospheric pressure (80 cm x $40 \mathrm{~cm} \times 30 \mathrm{~cm}$ ), equipped with a $24^{\circ} \mathrm{C}$ heat element contained around $50 \mathrm{M}$. fortunata shrimp. Temperature along the heating element was measured weekly using a temperature probe. The crabs did not survive the absence of high pressure conditions. (2) The Abyssbox, a $640 \mathrm{~kg}$ pressurised aquarium containing $16.5 \mathrm{~L}$ of flowing seawater, hosted 12 M. fortunata shrimp and 5 S. mesatlantica crabs (Shillito et al. this issue). A pump raised the pressure in the tank to $18 \mathrm{MPa}$. A first temperature-regulation unit cooled the experimental vessel and the in-coming seawater, and therefore set the background temperature to $10^{\circ} \mathrm{C}$. A second unit heats a ring-shaped tube situated inside the aquarium in order to create a "hotspot" for the animals $\left(27^{\circ} \mathrm{C}\right)$. The aim was to recreate some of the conditions (pressure/ $\mathrm{T}^{\circ} \mathrm{C}$ ) encountered at $1700 \mathrm{~m}$ depth on Lucky Strike active edifices. The window used for observation is a conical shape viewport of $15 \mathrm{~cm}$ outside diameter (Shillito et al., this issue). In both setups (atmospheric and under pressure), animals were fed every 4 to 5 days, and several types of food were tested (blue mussel Mytilus edulis, green crab Carcinus maenas, velvet crab Necora puber), including vent mussels (Bathymodiolus azoricus) which had been frozen after the 2011 cruise. From the end of 2012, the main food source was Liptoaqua food pellets (Liptosa, Madrid, Spain). Animals in AbyssBoxes were fed without decompression using an isobaric line, which allowed the introduction of food without pressure variations (Shillito et al., this issue).

\subsubsection{Observation protocol}

Observations were conducted during 13 weeks from April to June 2013 using a digital camera for the classic tank and direct observation for the AbyssBox (Table 1). Considering the differences in experimental conditions between the two setups, the classic tank was mainly used to characterize feeding behaviour, while observations in the AbyssBox focused 
on intra- and inter-specific interactions. In the standard tank, data consisted of 5 min video recordings of the shrimp, filmed before, during and after feeding (Table 1). Shrimp abundance, activity (resting, swimming, exploration, feeding) and positions (feeding zone, heat element, air pump or remaining area) were noted once a minute for each video recording (at $0,1,2,3$ and $4 \mathrm{~min}$ ). Due to the difficulty, in relation with the size, thickness and concavity of the window, in conducting quantitative observations in the AbyssBox, 5-minute notes taken 4 times an hour every week provided information on species behaviour, including aggregation, aggressions, displacements, positions, and antennae mobility (Table 1 and 2).

\subsection{Statistical analysis}

A non-parametric Friedman test (Mack and Skillings, 1980) was used to compare in situ mean densities on the different substrata and a Wilcoxon-Nemenyi-McDonald-Thompson post-hoc test determined which pairs of substrata were significantly different (Hollander and Wolfe, 1999). The influence of the timing (week, day/night, minutes, feeding phase) and fluid flux on species abundances were tested using a one- or two-way analyses of variance (ANOVAs), or a non-parametric Kruskal-Wallis test when data were not normally distributed and/or variances were not homogeneous. When tests indicated significant differences, Tukey's multiple comparisons test (HSD and the Wilcoxon post-hoc tests) were used to determine the relationships between the levels of the factor in question. Whittaker-Robinson periodograms were applied to screen for periodicities in each environmental variable measured (i.e., dissolved oxygen concentration, temperature and fluid flow velocity) and permutation tests were used to estimate the corresponding p-values (Legendre and Legendre, 2012). Data must be stationary before plotting the periodogram, i.e., significant linear trends were eliminated by calculating regression residuals (Legendre and Legendre, 2012). All analyses were carried out using the R statistical program (R Core Team 2014). 


\section{Results}

\subsection{In situ observations}

\subsubsection{Environmental conditions}

Bare substratum was the most represented substratum, accounting for $50 \%$ of the field of view, followed by mussel assemblages (19\%), anhydrites (15\%), the probe (9\%), unknown substratum (4\%), microbial mats $(2 \%)$ and anemones $(1 \%)$. The temperature and oxygen probe provided information on environmental conditions at a single point located in the middle of the field of view (Fig. 2) and did not describe conditions experienced at the smaller organism scale. For this reason temperature and oxygen data were only used as a proxy for environmental events at the vent scale (large-scale patterns).

The full continuous time series showed temperature variations from 4.4 to $9.5{ }^{\circ} \mathrm{C}$ and dissolved oxygen saturation from 55.3 to $85.7 \%$ (Fig. 3A). The period from December 2011 to February 2012 displayed a larger variability in environmental conditions with a higher mean temperature of $5.84{ }^{\circ} \mathrm{C} \pm 0.74{ }^{\circ} \mathrm{C}$ and a mean oxygen saturation of $68.6 \% \pm 4.1 \%$ (against $5.12{ }^{\circ} \mathrm{C} \pm 0.34^{\circ} \mathrm{C}$ and $77 \% \pm 2.78 \%$, respectively, during the rest of the year) (Fig. 3A). Fluid flow velocity, assessed from the video sequences, was highly variable at a weekly scale but generally stable over the year (Table 3). Periodograms computed for temperature and oxygen concentrations measured in January depicted peaks of significance at 12 and 25 hours, corresponding to the semi-diurnal signal and its harmonics. No significant periodicity was detected for fluid flow velocity.

\subsubsection{Spatial species abundances and distribution}


A total of 45,607 Mirocaris fortunata and 830 Segonzacia mesatlantica occurrences were counted in 320 video sequences corresponding to 10 hours and 40 minutes of images. A video sequence featured a mean of 142.5 and 2.6 individuals of $M$. fortunata and $S$. mesatlantica, respectively. The abundance of shrimp largely dominated that of the crabs over the entire sampling period. The analysis of the continuous time-series recorded in January provided slightly higher mean abundances for both species (145.8 and 3.3 ind $\mathrm{m}^{-2}$ in January; 137.8 and 2.4 ind $\mathrm{m}^{-2}$ from July 2011 to March 2012). Both shrimp and crab densities significantly differed among substratum types (shrimp: Friedman chi-squared $=1464.26$, df $=$ 5 , p-value $<2.2 \mathrm{e}^{-16} ;$ crab: Friedman chi-squared $=7701.26$, df $=5$, p-value $<2.2 \mathrm{e}^{-16}$ ) and occurred in higher abundances in mussel beds and anhydrites (Fig. 4). Fifty seven percent of M. fortunata individuals occupied mussel beds, while others occupied anhydrite deposit substratum, in particular those found in the main axis of hydrothermal flow (B1, B2, B3, Fig. 2). Bare substratum was the third most frequented substratum, probably because of its close proximity to hydrothermal emissions. While the shrimp's distribution was relatively constant over the study, the distribution of crabs was more heterogeneous, with highest crab occupancy shifting between mussel beds and anhydrites from one sampling period to another (Fig. 4). The substrata covered with anemones showed higher crab occupancy (2.3\%) than shrimp (1.2\%). However, results must be interpreted with caution considering the lower number of crabs compared to shrimp.

\subsubsection{Temporal species abundances and distribution}

Shrimp abundance varied over the 9 months (ANOVA, $F=25.56$, d.f. $=8, P<0.001$ ), with significantly lower abundances in July 2011 as well as in February and March 2012 (Fig. 3B). In January, abundances also varied from week to week (ANOVA, $F=12.07$, d.f. $=3, P$ $<0.001$ ), with a significantly higher abundance in the fourth week during which measured 
temperatures were lower compared to the first three weeks (Fig. 3C). The period of the day had no effect on the abundances observed (two levels: day, 06:00 to 12:00; night, 00:00 to 18:00). M. fortunata abundance did not display any significant periodicity. Shrimp spatial distribution in both the discontinuous or continuous time series did not vary significantly over time. The three grid cells (B1, B2, B3) located in the main axis of the hydrothermal flow contained an average of $60 \%$ of the shrimp observed in the video sequences (Fig. 2).

Segonzacia mesatlantica crabs showed variable abundances among months (KruskalWallis test, $\mathrm{P}<0.001$ ), with a significantly higher abundance in January 2012. Their abundance did not vary between weeks in January (Kruskal-Wallis test, $P=0.06$ ). Given that crabs were much less abundant, the evenness of their distribution could not be analyzed statistically. Their distribution resembled that of shrimp with crabs being most abundant in the main axis of hydrothermal flow (i.e., grid cells B1, B2 and B3). During the discontinuous time-series, an average of $63 \%$ of the crabs was located in the axis of fluid emission as compared with $76 \%$ in January. Most of them (43\%) were found in the B2 cell (mussel bed), while only $16 \%$ were observed in the B3 cell (anhydrite deposits).

Fluid flow velocity did not significantly affect total Mirocaris fortunata abundance (ANOVA, $F=0.151 ; P=0.980$ ), or Segonzacia mesatlantica abundance (Kruskal-Wallis test, $P=0.381)$ at the weekly sampling frequency.

\subsubsection{Species behaviour}

Various types of encounters characterized interspecific interactions between Mirocaris fortunata and Segonzacia mesatlantica. In general, both species were frequently in close proximity to one another resulting in inevitable contacts considering the small surface area 
involved $\left(1.13 \mathrm{~m}^{2}\right)$. Of the 233 video recordings analyzed between July 2011 and March 2012, 242 contact events occurred between the two species, with an average of one contact every 2 minutes (Table 4). These contacts all resulted in one or more shrimp fleeing, with the exception of one contact event that did not yield any reaction. Out of the 242 contacts, 573 shrimp fled (average of 2.5 escapes per video recording). Shrimp swam away for three reasons: (1) a crab moved towards them; (2) a shrimp moved within a centimeter contact of a crab; (3) secondary flights, i.e., triggered without direct visible cause mainly occurring after shrimp had already fled a previous contact, mostly due to crab movements. S. mesatlantica displayed a total of 31 events of specific behaviour towards shrimp, resembling attacks. Of these, 12 involved slow and furtive movements followed by rapid threatening motions, sometimes accompanied by claw activity, but could not be catalogued as predator behaviour since no shrimp were ever captured (video supplemental material 1). The other 19 events resembled territorial behaviour: crabs moved several centimeters and/or waved their claws towards a shrimp that had ventured too close.

For Mirocaris fortunata, intraspecific interactions observed during this study involved social behaviour with $98 \%$ of individuals occurring in aggregations. Frequent contacts between individuals occurred especially in the hydrothermal flow, the area characterized by the highest densities of individuals. Crustaceans possess two pairs of sensory organs: a pair of small antennules and a pair of antennae which functions are mainly olfaction and sensing touch (Bauer, 2004). Most intraspecific contacts involved antennae and antennules, but the video quality did not allow a more specific characterisation of their respective role. Only one individual of $M$. fortunata latched onto the back of another individual for several seconds. Contrastingly, Segonzacia mesatlantica was generally solitary. Over the 9 months, an average of $18 \%$ of the crabs was found within less than $10 \mathrm{~cm}$ of another crab. Out of 3 intraspecific 
contact events noted, only one caused another crab to escape in the mussel bed. In the January continuous time-series, where crabs occurred in higher density, $27 \%$ of the crabs were aggregated and 6 intraspecific contacts were recorded. In contrast to the discontinuous series, contacts caused aggressive behaviour that involved claw attacks for 5 seconds followed by another lasting 4 seconds.

\subsection{Ex situ observations}

\subsubsection{Classic tank}

Fig. 5 illustrates the variation in shrimp abundances in the 3 different zones of the standard tank before, during and after feeding. Overall, Mirocaris fortunata abundance was significantly higher $($ Kruskal-Wallis chi-squared $=128.7477, \mathrm{df}=2$, p-value $<2.2 \mathrm{e}-16$ ) around the heat source with an average of 15 individuals out of 23 . However, when food was introduced, shrimp significantly migrated towards the feeding zone (Table 5), particularly during the last 3 minutes (out of 5) of the video recording (Tukey's HSD post-hoc tests) with an average of 14 individuals found in the area compared to 5 individuals $1 \mathrm{~h}$ after, when the initial state is restored. When fed, some individuals directly dropped from the heating element on the mussel's/crab's flesh while others first explored the bottom of the tank before finding the resource. This exploration phase was accompanied by antennae's motions. Some individuals of $M$. fortunata were observed feeding on the exuviae of other shrimp. Video observations showed that shrimp only moulted on the heat source and their exuviae fell to the bottom of the tank. Every week, exuviae appeared and then disappeared, having been entirely consumed.

Aggregating behaviour in M. fortunata occurred in areas with higher temperature, i.e., on the surface of the heating element but with temperature being heterogeneous along the heat source. In almost all of the video recordings, aggregations occurred exactly where the 
temperature was the highest $\left(27.8{ }^{\circ} \mathrm{C}\right.$ at the water-substrate interface). Out of 12 shrimp on the heating element, 9 were aggregated on a very small surface $\left(\mathrm{ca} .8 \mathrm{~cm}^{2}\right)$ leading to many intraspecific interactions, often through the use of their antennae. The four types of recurring shrimp behaviour included: (1) vertical movements or "jolts"; out of 16, 8 resulted from antenna-antenna contact, 3 from antenna-body contact, 3 aimed at removing a shrimp that landed on the individual's back and 2 with no apparent reason; (2) form of coupling where one individual grabs onto the back of another, riding it for several seconds or minutes; (3) chasing conspecifics over several centimeters; and (4) aggressive behaviour with abrupt appendage or tail movements. When individuals were completely still, antennae were folded back along their bodies while when they were in motion, their antennae were unfolded and moving around. Antenna-antenna or antenna-body contacts only occurred when the antennae were in an unfolded position.

\subsubsection{AbyssBox}

Segonzacia mesatlantica crabs were significantly more active during feeding (Kruskall-Wallis test, $\mathrm{P}<0.001$ ). Likewise, feeding phase also increased $M$. fortunata mobility (ANOVA, $\mathrm{F}=14.71 ; \mathrm{df}=2, \mathrm{p}$-value $=3.80 .10^{-4}$ ). These statistical results corroborate the observations of individual migration towards the feeding outlet confirming the ability of this species to sense food in close proximity (at least $20 \mathrm{~cm}$ ). These displacements led to interspecific interactions: while crabs quickly dominated the feeding area, shrimp moved away, benefiting from leftovers and/or any suspended particles farther away from the outlet.

Despite the small size of the AbyssBox tank, few interspecific interactions occurred between the 12 shrimp and 5 crabs present. Most of the time, the two species occupied different areas of the AbyssBox (Table 6). Segonzacia mesatlantica was mainly found on the 
upper part of the grid (46\%) from which they could easily hang, and on the insulation foam around the electric cord for the heat source (30\%). Contrastingly, over 56\% of shrimp were found on the heat source (insulation foam and electric cord); the second most frequented area was the bottom of the tank, where $19 \%$ of them congregated. Both species interacted mainly during feeding time. Crabs initiated most of the interactions, which were either aggressive behaviour involving claw motions or contacts, both triggering shrimp escapes. Shrimp initiated interactions less frequently with only 3 contact events recorded with the crabs also resulting in shrimp fleeing.

Segonzacia mesatlantica intraspecific interactions were frequent and involved direct contacts when individuals were active and moving around. The AbyssBox tank was small, so the probability of touching a conspecific was greater than in situ. These contacts often caused aggressive reactions that ended in claw fights with one individual fleeing. Aggressiveness was even more pronounced during feeding, with claws poised in an attack position and abrupt movements.

\subsection{Comparison of in situ and ex situ data}

The in situ and ex situ video data were compared to investigate the role of different types of factors that may influence the observed behaviour: feeding, pressure, or temperature. Shrimp individuals were considered to be active when moving over a distance greater than the length of its body, feeding or exploring the substrate. The percentage of active shrimp differed between in situ and ex situ experiments, but also between the atmospheric pressure tank and the AbyssBox (both ex situ), particularly during feeding times (Table 7). Shrimp were more active in situ than in the artificial tank, both during and outside feeding times. In ex situ conditions, shrimp were generally more active during feeding times and under high pressure conditions (AbyssBox, 180 bars). 


\section{Discussion}

This study describes for the first time the behaviour of two hydrothermal Mid-Atlantic crustacean species, Mirocaris fortunata and Segonzacia mesatlantica, with respect to their physico-chemical environment. In addition, the comparison between in situ and ex situ data brought insights into different biotic interactions that should be taken into account in the understanding of factors shaping hydrothermal benthic communities.

4.1. Spatial distribution of the two species and links to the environment

Our observations confirmed that Mirocaris fortunata and Segonzacia mesatlantica preferentially colonize Bathymodiolus azoricus mussel beds and anhydrite deposits on the Eiffel Tower edifice (Cuvelier et al., 2009; Sarrazin et al., 2014). In this study, these habitats were also the ones located within the fluid flow axis where densities were the highest. $M$. fortunata form aggregations in close proximity of the warm water flow and, although often observed among mussels, they are widely distributed throughout a wide range of vent habitats (Desbruyères et al., 2001; Cuvelier et al., 2009, 2011a). Densities observed are in concordance with values observed in assemblages containing large $(>4 \mathrm{~cm})$ mussels (assemblage 1; Cuvelier et al., 2009, 2011a, 2012). Spatial distribution of M. fortunata was stable over the year analysed. However, the highest shrimp densities were observed within the fluid flow axis more likely in relation with their nutritional requirements as they may feed on species relying on bacteria or on bacteria themselves (Gebruk et al., 2000). Furthermore exsitu experimental results showed that shrimp individuals were only active when food was available. We therefore propose that $M$. fortunata distribution in its natural environment is mainly driven by resource availability. 
Segonzacia mesatlantica densities were on average low in contrast to densities previously reported both from imagery and samples (Cuvelier et al., 2012) which can be explained by the small surface area observed. Indeed, a greater imaged surface (ROV transects covering the entire structure) provided a higher mean density of crabs (Cuvelier et al., 2012), suggesting that the observed area is not sufficient to estimate mean densities of large macrofauna and that our sample is therefore not representative of the crab/mobile fauna local population. This highlights the importance of side studies to extend the spatial footprint of single point data. S. mesatlantica is highly mobile and was described as opportunistic in relation to food availability and substrata, independently of physico-chemical conditions (Cuvelier et al., 2009). Here, similarly to shrimp, they appeared more abundant in the fluid flow axis, but no significant relationship was found with the velocity indices extracted from video imagery (Sarrazin et al., 2009). Direct measurements in the field would be necessary to more thoroughly evaluate the influence of fluid flow on species distribution and abundance.

In the standard tank, shrimp were primarily found near the heating element, which provides a source of warmth. Similarly, in the AbyssBox, crabs and shrimp shared the space around the heating element. Measured temperature in the various shrimp sampled habitats at Eiffel Tower ranged from 5 to $24{ }^{\circ} \mathrm{C}$ (Desbruyères et al., 2001; Shillito et al., 2006; Cuvelier et al., 2011a; Sarrazin et al., this issue). In pressurized aquaria, Mirocaris fortunata shrimp can survive at temperatures between $10^{\circ} \mathrm{C}$ and $25^{\circ} \mathrm{C}$, and they become hyperactive above $25^{\circ} \mathrm{C}$, which was qualified as the beginning of the discomfort zone (Shillito et al., 2006). In the classic tank, shrimp clustered on the heat element where the temperature varied between $20.2^{\circ} \mathrm{C}$ and $27.8^{\circ} \mathrm{C}$, with an unexpected preference for the highest temperature. In a recent study, individuals of $M$. fortunata maintained at ambient pressure selected a mean temperature of $19.2 \pm 1.1^{\circ} \mathrm{C}$ (Smith et al., 2013). Hydrothermal species preferentially occupy 
thermal areas much cooler than their upper thermal limits to maintain a safety margin against rapid temperature fluctuations and the concomitant fluid toxicity (Bates et al., 2010). After a year in the tank, M. fortunata might have acclimated to constant (absence of temporal variation) thermal conditions and moved their upper selected temperature in response. Accurate observations starting on the first day of captivity are needed to confirm this hypothesis. On the other hand, these results also suggest that other parameters (e.g., sulphide concentrations, biotic factors) and not temperature could be the main limiting factor in natural shrimp distribution (Sarrazin et al., this issue). Finally, the difference of temperature preferendum might be linked to a combined effect of pressure and temperature. Indeed, pressure affects organisms physiology (reviewed in Pradillon and Gaill, 2007), their responses to temperature is therefore more likely to vary under different pressure conditions.

\subsection{Temporal variations of the natural environment}

Temperature and oxygen data confirmed a diurnal tidal influence already observed at this site (Sarrazin et al., 2014). A semi-diurnal tidal cycle has been detected in vent fluid temperature on the Juan de Fuca ridge (Tivey et al., 2002; Cuvelier et al., 2014) and the East Pacific Rise (Scheirer et al., 2006) in the Northeast Pacific. The deep currents near the hydrothermal vent sources on the northern MAR, including the Lucky Strike vent field, follow a semi-diurnal tidal cycle of $12.5 \mathrm{~h}$ (Khripounoff et al., 2008). Mechanisms involved in tide-related variability include changes in hydrostatic pressure (Davis and Becker, 1999) and the lateral distortion of the vent effluent plume following near-bottom tidal currents (Scheirer et al., 2006). The absence of a distinct pattern in our vent fluid velocity estimates is more likely related to the sampling interval (once a week over the year) and the estimation method. 
A tidal-related periodicity was observed in the opening and closing of a tubeworm community at the population level (Cuvelier, et al. 2014). Symbiotic sessile species need alternate input of oxygen and reduced compounds (sulphide or methane) to satisfy their symbiotic nutritional requirements and will thus take advantage of the horizontal advection of hydrothermal fluids by near-bottom tidal currents (Scheirer et al., 2006). This environmental constraint does not affect the highly mobile non-symbiotic shrimp Mirocaris fortunata, possibly explaining the apparent independence to tidal currents. Similar to environmental conditions, the sampling interval choice cannot be ruled out, as a periodicity can be blurred by over-influent effects with correspondence to biological traits or environmental events (Matabos et al., 2013).

\subsection{Feeding behaviour}

Our observations shed light on some possible patterns of feeding behaviour in both decapod species. Mirocaris fortunata, due to their heightened activity in the axis of hydrothermal flow, seem to graze directly on the substrate, either on mussel shells or anhydrite deposits, where they will most likely find microorganisms that grow and possibly organic debris that accumulate on the substratum. Both of these potential food sources have been identified in previous isotope analyses (Gebruk et al., 2000; Colaço et al., 2002; De Busserolles et al., 2009). The wide spectrum of isotope signatures measured places $M$. fortunata as an opportunistic species which is consistent with the large range of habitats they occupy (Desbruyères et al., 2001; Colaço et al., 2002). While feeding behaviour was easier to observe ex situ, the experimental setting was not used to determine food diets but rather to help reveal specific behavioural patterns. Aquarium observations suggest that organic debris might include their own exuviae and the remains of other hydrothermal species, placing them as scavengers. From experiments conducted in an atmospheric pressure tank, Gebruk et al. 
(2000) noted that M. fortunata used their antennae to explore mussel and shrimp tissues before using their chelae to cut and consume the tissue. Here, it was also observed that shrimp can temporarily move away from the heat source to explore the bottom of the tank to find the feeding zone when food is made available. This suggests shrimp can detect and then orient themselves towards the food source. Indeed, during this exploration phase shrimp displacements were associated with antennae motions. As in other shrimp species, their antennae may play an important role as receptors that help them navigate in their environment and sense the arrival of new feeding sources (Ache and Derby, 1985; Renninger et al., 1995). A short delay in reaction time to food availability was statistically demonstrated for $M$. fortunata in the standard tank, possibly representing the time to activate the receptors that detect food. While Gebruk et al. (2000) showed that only 1 or 2 shrimp were attracted by the food at any given time, shrimp distribution in our experimental set-up significantly changed during feeding time with higher densities in the feeding zone. The introduction of food increased crustacean activity in both aquaria, although shrimp were constantly active in their natural environment. This behavioural change was probably due to the fact that food was not continuously available in the experimental set-up, and shrimp densities were low in contrast to the natural environment (see also 4.5: In situ versus ex situ data).

Segonzacia mesatlantica was described as both necrophagous (i.e., a scavenger), feeding on the remains of mussels and shrimp, including exuviae (Desbruyères et al., 2006) and, from isotope analysis, as a predator of shrimp, other small invertebrates (Colaço et al., 2002) and small Bathymodiolus mussels (De Busserolles et al., 2009). Isotope analyses indicate that crabs occupy a predator/scavenger position in the food web on the Eiffel Tower (De Busserolles et al., 2009). Preliminary analysis of 2 years of video and a few weeks of observations in the AbyssBox failed to observe any scavenging or predation event (this study, 
Sarrazin et al., 2014). A crab was observed feeding on a shrimp in situ, but not catching it (J. Sarrazin, personal observations). Crabs are often present at sites containing broken mussel shells which could be linked to the crabs feeding strategy of using crushing or opening tactics (Moody and Steneck, 1993). Recently, during the MoMARSAT 2014 cruise, a crab was observed grabbing a mussel with its claws, bringing it into its 'hollow' and seemed to be feeding on it (J. Sarrazin, personal observations, video supplemental material 2). In this study, the rare events of aggressive behaviour, resembling attacks of crabs towards shrimp, never led to feeding or ripping apart tissues, neither in situ, nor in the AbyssBox. Those observations raise questions regarding the crabs feeding mode. Stable isotope ratios and lipid analyses are powerful tools to infer species diet and trace trophic pathways to characterize the vent ecosystem (Rau and Hedges, 1979; Fry and Sherr, 1989; Conway et al., 1994), but only informs on the trophic level and the source of food. One cannot infer trophic mode, and differentiation between scavenging and predation. Only direct observations will allow a comprehensive understanding of feeding modes. The fact that $M$. fortunata and $S$. mesatlantica could be kept alive in an aquarium in standard seawater without any of the compounds found in hydrothermal sources, nor its associated microbial fauna, demonstrates that these species can survive in the absence of chemo-autotrophic bacteria, or physicochemical conditions from the seawater of their native ecosystem.

\subsection{Biotic interactions}

The interactions between shrimp and crabs appeared to be solely triggered by close proximity. Mirocaris fortunata is a social species and occupied most of the available space in the axis of the hydrothermal flow. Although often immobile or nearly so, crabs did not appear to appreciate contact with shrimp. They react quickly, with abrupt claw movements, causing the shrimp to flee and leave the immediate area. All observed crab actions towards shrimp 
indicated that Segonzacia mesatlantica is territorial. Crab territoriality is further supported by the fact that some crabs remain in the same place, often hidden in hollows within the mussel bed or anhydrite deposits, for long periods of time (up to several days) and return to the same place after any absence (authors, personal observations). Territoriality can also be inferred from their solitary behaviour. Although the few contacts between crabs generally did not provoke a reaction, one contact event did result in an aggressive face-off that lasted several seconds. In contrast to their natural environment, there was limited space available in the AbyssBox, and so the probability of conspecific contacts was greater. Confrontation events showed rivalry between crabs and defence postures. This behaviour was even more pronounced during feeding time, with the crabs defending their access to food. Clustering towards the food source also caused aggressive behaviour towards shrimp. They were being chased away if they were near the food or in its pathway in the AbyssBox. Aggressiveness for access to food had never been observed in situ probably due to the presence of unlimited resource, or a lack of feeding observations. Similarly, a coastal hermit crab species increases aggressive behavior when food is limited (Ramsay et al., 1997).

Mirocaris fortunata behaviour sharply contrasted with that of Segonzacia mesatlantica; most lived in aggregation and only few individuals were found isolated. Previous studies suggested that aggregation in aquatic crustaceans is a strategy to optimise energy expenditure, maximise food capture (Ritz, 2000), increase proximity to mates, reduce predation and maintain a position in a favourable habitat (Ambler, 2002). At this depth, there is no light and faunal species cannot orient themselves using light. Therefore, touch and specific (chemo- or thermo-) receptors are the only senses that help them perceive the environment. The hydrothermal shrimp M. fortunata, Chorocaris chacei and Rimicaris exoculata have no image-forming optics but powerful photoreceptors that would detect 
infrared radiation emitted from hydrothermal vents to help maintain their position in the fluid (O'Neill et al., 1995; Kuenzler et al., 1997; Chamberlain, 2000; White et al., 2002). In addition, the absence of direct contact in secondary flights implies that vibrations or chemical cues are involved in inter-individual communication. The important role of antennae and antennules in shrimp communication has already been described for detecting chemical signals (Ache and Derby, 1985; Renninger et al., 1995) but also in social behaviour (Vickery et al., 2012). No study of this type has been carried out specifically on M. fortunata, but it is likely that antennae play a more fundamental role in shrimp orientation, helping them to find areas of active hydrothermal emissions and for aggregating with conspecifics. Observations in the standard tank and the AbyssBox confirmed that $M$. fortunata intraspecific interactions involved antennae contacts. Nevertheless, our study does not offer any explanation regarding the mechanisms involved in communication via antennae, or the differences between antennaantenna or antenna-body contacts. A research project has been recently initiated by our team to study the role of shrimp antennae and antennules in communication, interactions and sensing. The coupling of individuals may have been part of reproductive behaviour, as suggested by the regular presence of gravid females in the tanks during maintenance operations (Shillito and Barthelemy, personal observations). This behaviour involved an individual hatching on the back of another and riding it for a few seconds.

\subsection{In situ versus ex situ data: the use of live specimens in aquarium for ecological studies}

In artificial ex situ environments, the species were more passive compared to the in situ environment. The lack of stimulation resulting from the stable conditions in the tank compared to the in situ highly dynamic environment, the lower animal densities and the absence of a continuous food source may explain the differences in behaviour. In addition, we cannot rule out a loss in animal condition during the process (from sampling to Océanopolis). 
However, higher mortality rates occurred in the first days following sampling and during transport (Shillito et al., this issue). Upon arrival at Oceanopolis, mortality dropped sharply after 10 days suggesting that the remaining individuals used in this study have started to acclimate with respect to their maintenance conditions (Shillito et al., this issue). We can therefore assume that animals observed in this study are in fairly good condition; they all showed signs of activity and feeding. This dominant ex situ passiveness causes other differences in interactions. There were virtually no interspecific interactions in the AbyssBox where the shrimp rarely came in contact with the crabs, and fewer intraspecific interactions occurred compared with in situ hydrothermal conditions. Therefore, artificial environments seemed to lead to changes in behaviour in both species. In addition, atmospheric pressure also influenced the activity level of shrimp as they were more active in the AbyssBox than in the standard aquarium, except during feeding.

Aquarium observations, because of their easier accessibility, provided a higher diversity and complexity of intraspecific interactions that are difficult to observe on in situ videos because of the larger field of view. Future zoomed-in videos will allow a better in situ characterization of organisms' behaviour. Live shrimp have now been kept in pressurized aquarium for more than 3 years. Long-term observations and experimental set-ups will help document feeding and reproductive behaviour and better define interactions as well as the mechanisms involved. Combined with the data coming from the EMSO-Açores MoMAR deep-sea observatory, which provides long-term continuous observation of a Bathymodiolus azoricus vent mussel assemblage, observations in experimental conditions using the AbyssBox will help to better understand local processes shaping benthic community structure. Indeed, conducting in situ experiments to characterize the relative role of biotic interactions on community structure is complex in deep-sea vents because of the limited accessibility. Pressurized aquaria such as the AbyssBox, in which the environmental conditions are controlled and can be modified, will 
help characterize the mechanisms by which biotic interactions influence species distribution. While to date, only two hydrothermal species were successfully sampled and transferred to the AbyssBox, we hope in the future to rear other species as well.

\section{Conclusions}

This preliminary behavioural study provides a basis for further research on hydrothermal species. Direct in situ observations with the use of cameras deployed on deepsea observatories, complemented with experimental set-up in pressurized aquaria, will continue to provide information on species behaviour, interactions and reactions to local environmental changes. These data are essential to better understand the relative role of biotic and abiotic factors in structuring hydrothermal vent communities. Results show that both species strongly respond to food source, often leading to aggressive behaviour, highlighting the importance of resource availability, and most likely competition for food, in controlling the distribution and behaviour of both decapod species at vents. Also, both species, and even more particularly Mirocaris fortunata, can survive away from their natural environmental conditions and can adapt to high variation in bio-physico-chemical variables (both species survived well in coastal seawater without requiring any chemical input to simulate their natural environment). However, those conditions are not optimal as none of the individuals have completed a full reproductive cycle yet, and crabs did not survive long at atmospheric pressure nor showed any signs of molting.

\section{Aknowledgements}

We thank the captain and crews of the R/V Pourquoi pas? as well as the pilots of the ROV Victor6000 for their assistance and support during the MoMARSAT cruises. We thank the engineers who designed the TEMPO module and participated to the 
maintenance cruises: Jérôme Blandin, Jean-Yves Coail, Laurent Delauney, Anthony Ferrant, Gérard Guyader, Agathe Laes, Julien Legrand, Pascal Pichavant. We are also grateful to the deep-sea lab support team: Nicolas Gayet, Philippe Noel, and Philippe Rodier. We thank Julie Tourolle and Stevenn Lamarche for their help with the map. We also thank Jean-Marie Carré, Olivier Gouello and the Oceanopolis aquariology team for their support with the ex situ experiments.

\section{References}

Ache, B.W., Derby, C.D., 1985. Functional organization of olfaction in crustaceans. Trends Neurosci. 8, 356-360.

Ambler, J., 2002. Zooplankton swarms: characteristics, proximal cues and proposed advantages. Hydrobiologia 480, 155-164.

Auffret, Y., Coail, J.-Y., Delauney, L., Legrand, J., Dupont, J., Dussud, L., Guyader, G., Ferrant, A., Barbot, S., Laes, A., 2009. Tempo-Mini: a custom-designed instrument for real-time monitpring of hydrothermal vent ecosystems. Instrum. Viewp. 17.

Bates, A., Tunnicliffe, V., Lee, R., 2005. Role of thermal conditions in habitat selection by hydrothermal vent gastropods. Mar. Ecol. Prog. Ser. 305, 1-15. doi:10.3354/meps305001

Bates, A.E., Bird, T.J., Robert, K., Onthank, K.L., Quinn, G.P., Juniper, S.K., Lee, R.W., 2013. Activity and positioning of eurythermal hydrothermal vent sulphide worms in a variable thermal environment. J. Exp. Mar. Bio. Ecol. 448, 149-155. 
Bates, A.E., Lee, R.W., Tunnicliffe, V., Lamare, M.D., 2010. Deep-sea hydrothermal vent animals seek cool fluids in a highly variable thermal environment. Nat. Commun. 1, 14. doi:10.1038/ncomms1014

Bauer, R.T., 2004. Remarkable shrimps: adaptations and natural history of the carideans. Oklahoma University Press, Norman, OK.

Blandin, J., Colaço, A., Legrand, J., Cannat, M., Sarradin, P.M., Sarrazin, J., 2010. The MoMAR-D project : a challenge to monitor in real time the Lucky Strike hydrothermal vent field. ICES J. Mar. Sci. 68, 416-424.

Blandin, J., Rolin, J.F., 2005. An array of sensors for the seabed monitoring of geohazards-A versatile solution for the long-term real-time monitoring of distributed seabed parameters. Sea Technol. 46.

Cannat, M., Briais, A., Deplus, C., Escartín, J., Georgen, J., Lin, J., Mercouriev, S., Meyzen, C., Muller, M., Pouliquen, G., 1999. Mid-Atlantic Ridge-Azores hotspot interactions: along-axis migration of a hotspot-derived event of enhanced magmatism 10 to $4 \mathrm{Ma}$ ago. Earth Planet. Sci. Lett. 173, 257-269.

Cannat, M., Sarradin, P., Blandin, J., Escartin, J., Colaco, A., 2011. MoMar-Demo at Lucky Strike. A near-real time multidisciplinary observatory of hydrothermal processes and ecosystems at the Mid-Atlantic Ridge. In: AGU Fall Meeting, Abstract OS22A-05, San Francisco.

Chamberlain, S.C., 2000. Vision in hydrothermal vent shrimp. Philos. Trans. R. Soc. Lond. B. Biol. Sci. 355, 1151-1154. doi:10.1098/rstb.2000.0657 
Chevaldonné, P., Jollivet, D., 1993. Videoscopic study of deep-sea hydrothermal vent alvinellid polychaete populations: biomass estimation and behaviour. Mar. Ecol. Prog. Ser. 95, 251.

Colaço, A., Blandin, J., Cannat, M., Carval, T., Chavagnac, V., Connelly, D., Fabian, M., Ghiron, S., Goslin, J., Miranda, J.M., 2011. MoMAR-D: a technological challenge to monitor the dynamics of the Lucky Strike vent ecosystem. ICES J. Mar. Sci. J. du Cons. $68,416-424$.

Colaço, A., Dehairs, F., Desbruyères, D., 2002. Nutritional relations of deep-sea hydrothermal fields at the Mid-Atlantic Ridge: a stable isotope approach. Deep. Res. Part I Oceanogr. Res. Pap. 49, 395-412. doi:10.1016/S0967-0637(01)00060-7

Conway, N.M., Kennicutt, M.C., Van Dover, C.L., 1994. Stable isotopes in the study of marine chemosynthetic-based ecosystems, in: Lajtha, K., Michener, R. (Eds.), Stable Isotopes in Ecology. Blackwell Scientific, New York, pp 158-186.

Copley, J.T.P., Jorgensen, P.B.K., Sohn, R.A., 2007. Assessment of decadal-scale ecological change at a deep Mid-Atlantic hydrothermal vent and reproductive time-series in the shrimp Rimicaris exoculata. J. Mar. Biol. Assoc. U. K. 87, 859-867.

Copley, J.T.P., Tyler, P.A., Murton, B.J., Van Dover, C.L., 1997. Spatial and interannual variation in the faunal distribution at Broken Spur vent field $\left(29^{\circ} \mathrm{N}\right.$, Mid-Atlantic Ridge). Mar. Biol. 129, 723-733. doi:10.1007/s002270050215

Copley, J.T.P., Tyler, P.A., Van Dover, C.L., Philp, S.J., 2003. Spatial variation in the reproductive biology of Paralvinella palmiformis (Polychaeta: Alvinellidae) from a vent field on the Juan de Fuca Ridge. Mar. Ecol. Prog. Ser. 255, 171-181. 
Cuvelier, D., de Busserolles, F., Lavaud, R., Floc'h, E., Fabri, M.C., Sarradin, P.M., Sarrazin, J., 2012. Biological data extraction from imagery - How far can we go? A case study from the Mid-Atlantic Ridge. Mar. Environ. Res. 82, 15-27. doi:10.1016/j.marenvres.2012.09.001

Cuvelier, D., Legendre, P., Laes, A., Sarradin, P.-M., Sarrazin, J., 2014. Rhythms and community dynamics of a hydrothermal tubeworm assemblage at main Endeavour fielda multidisciplinary deep-sea observatory approach. PLoS One 9, e96924.

Cuvelier, D., Sarradin, P., Sarrazin, J., Colaço, A., Copley, J.T., Desbruyères, D., Glover, A.G., Santos, R.S., Tyler, P.A., 2011a. Hydrothermal faunal assemblages and habitat characterisation at the Eiffel Tower edifice (Lucky Strike, Mid Atlantic Ridge). Mar. Ecol. 32, 243-255.

Cuvelier, D., Sarrazin, J., Colaço, A., Copley, J., Desbruyères, D., Glover, A.G., Tyler, P., Serrão Santos, R., 2009. Distribution and spatial variation of hydrothermal faunal assemblages at Lucky Strike (Mid-Atlantic Ridge) revealed by high-resolution video image analysis. Deep. Res. Part I Oceanogr. Res. Pap. 56, 2026-2040. doi:10.1016/j.dsr.2009.06.006

Cuvelier, D., Sarrazin, J., Colaço, A., Copley, J.T., Glover, A.G., Tyler, P.A., Santos, R.S., Desbruyères, D., 2011b. Community dynamics over 14 years at the Eiffel Tower hydrothermal edifice on the Mid-Atlantic Ridge. Limnol. Oceanogr. 56, 1624-1640.

Davis, E., Becker, K., 1999. Tidal pumping of fluids within and from the oceanic crust: new observations and opportunities for sampling the crustal hydrosphere. Earth Planet. Sci. Lett. 172, 141-149. 
De Busserolles, F., Sarrazin, J., Gauthier, O., Gélinas, Y., Fabri, M.C., Sarradin, P.M., Desbruyères, D., 2009. Are spatial variations in the diets of hydrothermal fauna linked to local environmental conditions? Deep. Res. Part II Top. Stud. Oceanogr. 56, 1649-1664. doi:10.1016/j.dsr2.2009.05.011

Desbruyerès, D., Almeida, A., Biscoito, M., Comtet, T., Khripounoff, A., Le Bris, N., Sarradin, P.M., Segonzac, M., 2000. A review of the distribution of hydrothermal vent communities along the northern Mid-Atlantic Ridge: dispersal vs. environmental controls. Hydrobiologia 440, 201-216. doi:10.1023/A:1004175211848

Desbruyères, D., Biscoito, M., Caprais, J.C., Colaço, A., Comtet, T., Crassous, P., Fouquet, Y., Khripounoff, A., Le Bris, N., Olu, K., Riso, R., Sarradin, P.M., Segonzac, M., Vangriesheim, A., 2001. Variations in deep-sea hydrothermal vent communities on the Mid-Atlantic Ridge near the Azores plateau. Deep. Res. Part I Oceanogr. Res. Pap. 48, $1325-1346$.

Desbruyères, D., Chevaldonné, P., Alayse, A.M., Jollivet, D., Lallier, F.H., Jouin-Toulmond, C., Zal, F., Sarradin, P.M., Cosson, R., Caprais, J.C., Arndt, C., O’Brien, J., Guezennec, J., Hourdez, S., Riso, R., Gaill, F., Laubier, L., Toulmond, A., 1998. Biology and ecology of the "Pompeii worm" (Alvinella pompejana Desbruyeres and Laubier), a normal dweller of an extreme deep-sea environment: a synthesis of current knowledge and recent developments. Deep. Res. Part II Top. Stud. Oceanogr. 45, 383-422. doi:10.1016/S0967-0645(97)00083-0

Desbruyères, D., Segonzac, M., Bright M., 2006. Handbook of deep-sea hydrothermal vent fauna, Handbook of deep-sea hydrothermal vent fauna. Denisia, 18: 544p. 
Fisher, C.R., 1998. Temperature and sulphide tolerance of hydrothermal vent fauna. Cah. Biol. Mar. 39, 283-286.

Fouquet, Y., Ondreas, H., Charlou, J.-L., Donval, J.-P., Radford-Knoery, J., Costa, I., Lourenco, N., Tivey, M.K., 1995. Atlantic lava lakes and hot vents. Nature 377, 201.

Fry, B., Sherr, E.B., 1989. $\delta 13 \mathrm{C}$ measurements as indicators of carbon flow in marine and freshwater ecosystems. In: Stable Isotopes in Ecological Research. Springer, Heidelberg, pp. 196-229.

Gebruk, A.V., Southward, E.C., Kennedy, H., Southward, A.J., 2000. Food sources, behaviour, and distribution of hydrothermal vent shrimps at the Mid-Atlantic Ridge. J. Mar. Biol. Assoc. UK 80, 485-499. doi:10.1017/S0025315400002186

Glover, A. G., Gooday, A. J., Bailey, D.M., Billett, D.S.M., Chevaldonné, P., Colaço, A, Copley, J., Cuvelier, D., Desbruyères, D., Kalogeropoulou, V., Klages, M., Lampadariou, N., Lejeusne, C., Mestre, N.C., Paterson, G.L.J., Perez, T., Ruhl, H., Sarrazin, J., Soltwedel, T., Soto, E.H., Thatje, S., Tselepides, A., Van Gaever, S., Vanreusel, A., 2010. Temporal change in deep-sea benthic ecosystems: a review of the evidence from recent time-series studies. Adv. Mar. Biol. 58, 1-95. doi:10.1016/B978-0$12-381015-1.00001-0$

Govenar, B., Le Bris, N., Gollner, S., Glanville, J., Aperghis, A., Hourdez, S., Fisher, C., 2005. Epifaunal community structure associated with Riftia pachyptila aggregations in chemically different hydrothermal vent habitats. Mar. Ecol. Prog. Ser. 305, 67-77. doi:10.3354/meps305067 
Grehan, A.J., Juniper, S.K., 1996. Clam distribution and subsurface hydrothermal processes at chowder Hill (Middle Valley), Juan de Fuca Ridge. Mar. Ecol. Prog. Ser. 130, 105-115.

Grelon, D., Morineaux, M., Desrosiers, G., Juniper, S.K., 2006. Feeding and territorial behavior of Paralvinella sulfincola, a polychaete worm at deep-sea hydrothermal vents of the Northeast Pacific Ocean. J. Exp. Mar. Bio. Ecol. 329, 174-186.

Hessler, R.R., Smithey Jr, W.M., Keller, C.H., 1985. Spatial and temporal variation of giant clams, tube worms and mussels at deep-sea hydrothermal vents. Bull. Biol. Soc. Washington 6, 411-428.

Hessler, R.R., Smithey, W.M., Boudrias, M.A., Keller, C.H., Lutz, R.A., Childress, J.J., 1988. Temporal change in megafauna at the Rose Garden hydrothermal vent (Galapagos Rift; eastern tropical Pacific). Deep Sea Res. Part A. Oceanogr. Res. Pap. 35, 1681-1709. doi:10.1016/0198-0149(88)90044-1

Hollander, M.W., Wolfe, D.A., 1999. Nonparametric Statistical Methods, $2^{\text {nd }}$ Edn. John Wiley \& Sons, New York.

Ivanenko, V., Ferrari, F.D., Defaye, D., Sarradin, P.-M., Sarrazin, J., 2011. Description, distribution and microhabitats of a new species of Tisbe (Copepoda: Harpacticoida: Tisbidae) from a deep-sea hydrothermal vent field at the Mid-Atlantic Ridge (37 degrees N, Lucky Strike). Cah. Biol. Mar. 52, 89-106.

Johnson, K.S., Beehler, C.L., Sakamoto-Arnold, C.M., Childress, J.J., 1986. In situ measurements of chemical distributions in a deep-sea hydrothermal vent field. Science 231, 1139-1141. doi:10.1126/science.231.4742.1139 
Jollivet, D., 1996. Specific and genetic diversity at deep-sea hydrothermal vents: an overview. Biodivers. Conserv. 5, 1619-1653.

Juniper, S.K., Escartin, J., Cannat, M., 2007. Monitoring and observatories: multidisciplinary, time-series observations at mid-ocean ridges. Oceanography 20, 128-137.

Kelly, N.E., Metaxas, A., 2007. Influence of habitat on the reproductive biology of the deepsea hydrothermal vent limpet Lepetodrilus fucensis (Vetigastropoda: Mollusca) from the Northeast Pacific. Mar. Biol. 151, 649-662. doi:10.1007/s00227-006-0505-z

Khripounoff, A., Vangriesheim, A., Crassous, P., Segonzac, M., Lafon, V., Warén, A., 2008. Temporal variation of currents, particulate flux and organism supply at two deep-sea hydrothermal fields of the Azores Triple Junction. Deep Sea Res. Part I Oceanogr. Res. Pap. 55, 532-551.

Kuenzler, R.O., Kwasniewski, J.T., Jinks, R.N., Lakin, R.C., Battelle, B.A., Herzog, E.D., Kass, L., Renninger, G.H., Chamberlin, S.C., 1997. Retinal anatomy of new bresiliid shrimp from the Lucky Strike and Broken Spur hydrothermal vent fields on the MidAtlantic Ridge. J. Mar. Biol. Assoc. U. K. 77, 707. doi:10.1017/S0025315400036146

Langmuir, C., Humphris, S., Fornari, D., Van Dover, C., Von Damm, K., Tivey, M.K., Colodner, D., Charlou, J.-L., Desonie, D., Wilson, C., Fouquet, Y., Klinkhammer, G., Bougault, H., 1997. Hydrothermal vents near a mantle hot spot: the Lucky Strike vent field at $37^{\circ} \mathrm{N}$ on the Mid-Atlantic Ridge. Earth Planet. Sci. Lett. 148, 69-91. doi:10.1016/S0012-821X(97)00027-7

Lee, R.W., 2003. Thermal tolerances of deep-sea hydrothermal vent animals from the Northeast Pacific. Biol. Bull. 205, 98-101. 
Legendre, P., Legendre, L., 2012. Numerical ecology, $3^{\text {rd }}$ Edn. Elsevier, London.

Lenihan, H.S., Mills, S.W., Mullineaux, L.S., Peterson, C.H., Fisher, C.R., Micheli, F., 2008. Biotic interactions at hydrothermal vents: recruitment inhibition by the mussel Bathymodiolus thermophilus. Deep. Res. Part I Oceanogr. Res. Pap. 55, 1707-1717. doi:10.1016/j.dsr.2008.07.007

Luther, G., Gartman, A., Yücel, M., Madison, A., Moore, T., Nees, H., Nuzzio, D., Sen, A., Lutz, R., Shank, T., Fisher, C., 2012. Chemistry, temperature, and faunal distributions at diffuse-flow hydrothermal vents: comparison of two geologically distinct ridge systems. Oceanography 25, 234-245. doi:10.5670/oceanog.2012.22

Mack, G.A., Skillings, J.H., 1980. A Friedman-type rank test for main effects in a two-factor ANOVA. J. Am. Stat. Assoc. 75, 947-951.

Martin JW, Christiansen JC. 1995. A new species of the shrimp genus Chorocaris Martin and Hessler, 1990 (Crustacea, Decapoda, Bresiliidae) from hydrothermal vent fields along the Mid-Atlantic Ridge. Proceedings of the Biological Society of Washington 108, 220227.

Matabos, M., Bui, A.O. V., Mihály, S., Aguzzi, J., Juniper, S.K., Ajayamohan, R.S., 2014. High-frequency study of epibenthic megafaunal community dynamics in Barkley Canyon: a multi-disciplinary approach using the NEPTUNE Canada network. J. Mar. Syst. 130, 56-68.

Micheli, F., Peterson, C.H., Mullineaux, L.S., Fisher, C.R., Mills, S.W., Sancho, G., Johnson, G.A., Lenihan, H.S., 2002. Predation structures communities at deep-sea hydrothermal 
vents. Ecol. Monogr. 72, 365-382. doi:10.1890/00129615(2002)072[0365:PSCADS]2.0.CO;2

Moody, K.E., Steneck, R.S., 1993. Mechanisms of predation among large decapod crustaceans of the Gulf of Maine Coast: functional vs. phylogenetic patterns. J. Exp. Mar. Bio. Ecol. 168, 111-124. doi:10.1016/0022-0981(93)90118-8

Mullineaux, L.S., Fisher, C.R., Peterson, C.H., Schaeffer, S.W., 2000. Tubeworm succession at hydrothermal vents: use of biogenic cues to reduce habitat selection error? Oecologia 123, 275-284. doi:10.1007/s004420051014

Mullineaux, L.S., Peterson, C.H., Micheli, F., Mills, S.W., 2003. Successional mechanisms varies along a gradient in hydrothermal fluid flux at deep-sea vents. Ecol. Monogr. 73, 523-542. doi:10.1890/02-0674

Nye, V., Copley, J.T., Tyler, P.A., 2013. Spatial variation in the population structure and reproductive biology of Rimicaris hybisae (Caridea: Alvinocarididae) at hydrothermal vents on the Mid-Cayman spreading centre. PLoS One 8. doi:10.1371/journal.pone.0060319

O’Neill, P.J., Jinks, R.N., Herzog, E.D., Battelle, B.-A., Kass, L., Renninger, G.H., Chamberlain, S.C., 1995. The morphology of the dorsal eye of the hydrothermal vent shrimp, Rimicaris exoculata. Vis. Neurosci. $12, \quad 861-875$. doi:10.1017/S0952523800009421

Ondréas, H., Cannat, M., Fouquet, Y., Normand, A., Sarradin, P.M., Sarrazin, J., 2009. Recent volcanic events and the distribution of hydrothermal venting at the Lucky Strike 
hydrothermal field, Mid-Atlantic Ridge. Geochem., Geophys. Geosys. 10, 1-18. doi:10.1029/2008GC002171

Pradillon, F., Gaill, F., 2007. Pressure and life: some biological strategies. Rev. Environ. Sci. Biotechnol. 6, 181-196.

Ramsay, K., Kaiser, M.J., Hughes, R.N., 1997. A field study of intraspecific competition for food in hermit crabs (Pagurus bernhardus). Estuar. Coast. Shelf Sci. 44, 213-220.

Rau, G.H., Hedges, J.I., 1979. Carbon-13 depletion in a hydrothermal vent mussel: suggestion of a chemosynthetic food source. Science 203, 648-649. doi:10.1126/science.203.4381.648

Renninger, G.H., Kass, L., Gleeson, R.A., Van Dover, C.L., Battelle, B.A., Jinks, R.N., Herzog, E.D., Chamberlain, S.C., 1995. Sulfide as a chemical stimulus for deep-sea hydrothermal vent shrimp. Biol. Bull. 189, 69-76.

Ritz, D.A., 2000. Is social aggregation in aquatic crustaceans a strategy to conserve energy? Can. J. Fish. Aquat. Sci. 57, 59-67. doi:10.1139/f00-170

Robert, K., Onthank, K.L., Juniper, S.K., Lee, R.W., 2012. Small-scale thermal responses of hydrothermal vent polynoid polychaetes: preliminary in situ experiments and methodological development. J. Exp. Mar. Bio. Ecol. 420, 69-76.

Sancho, G., Fisher, C.R., Mills, S., Micheli, F., Johnson, G.A., Lenihan, H.S., Peterson, C.H., Mullineaux, L.S., 2005. Selective predation by the zoarcid fish Thermarces cerberus at hydrothermal vents. Deep Sea Res. Part I Oceanogr. Res. Pap. 52, 837-844. 
Sarradin, P.M., Caprais, J.C., Briand, P., Gaill, F., Shillito, B., Desbruyeres, D., 1998. Chemical and thermal description of the environment of the Genesis hydrothermal vent community (13 degree N, EPR). Cah. Biol. Mar. 39, 159-167.

Sarrazin, J., Blandin, J., Delauney, L., Dentrecolas, S., Dorval, P., Dupont, J., Legrand, J., Leroux, D., Leon, P., Lévèque, J.P., 2007. TEMPO: a new ecological module for studying deep-sea community dynamics at hydrothermal vents. In: OCEANS 2007Europe. Ieee, pp. 1-4.

Sarrazin, J., Cuvelier, D., Peton, L., Legendre, P., Sarradin, P.M., 2014. High-resolution dynamics of a deep-sea hydrothermal mussel assemblage monitored by the EMSOAçores MoMAR observatory. Deep Sea Res. Part I Oceanogr. Res. Pap. 90, 62-75. doi:10.1016/j.dsr.2014.04.004

Sarrazin, J., Juniper, S.K., Massoth, G., Legendre, P., 1999. Physical and chemical factors influencing species distributions on hydrothermal sulfide edifices of the Juan de Fuca Ridge, northeast Pacific. Mar. Ecol. Prog. Ser. 190, 89-112.

Sarrazin, J., Levesque, C., Juniper, S., Tivey, M., 2002. Mosaic community dynamics on Juan de Fuca Ridge sulphide edifices: substratum, temperature and implications for trophic structure. Cahiers Biol. Mar. 43, 275-279.

Sarrazin, J., Robigou, V., Juniper, S., Delaney, J., 1997. Biological and geological dynamics over four years on a high-temperature sulfide structure at the Juan de Fuca Ridge hydrothermal observatory. Mar. Ecol. Prog. Ser. 153, 5-24. doi:10.3354/meps 153005 
Sarrazin, J., Rodier, P., Tivey, M.K., Singh, H., Schultz, A., Sarradin, P.M., 2009. A dual sensor device to estimate fluid flow velocity at diffuse hydrothermal vents. Deep. Res. Part I Oceanogr. Res. Pap. 56, 2065-2074. doi:10.1016/j.dsr.2009.06.008

Scheirer, D.S., Shank, T.M., Fornari, D.J., 2006. Temperature variations at diffuse and focused flow hydrothermal vent sites along the northern East Pacific Rise. Geochem. Geophys. Geosys. 7. doi:10.1029/2005GC001094

Schöne, B.R., Giere, O., 2005. Growth increments and stable isotope variation in shells of the deep-sea hydrothermal vent bivalve mollusk Bathymodiolus brevior from the North Fiji Basin, Pacific Ocean. Deep. Res. Part I Oceanogr. Res. Pap. 52, 1896-1910.

Shank, T.M., Fornari, D.J., Von Damm, K.L., Lilley, M.D., Haymon, R.M., Lutz, R.A., 1998. Temporal and spatial patterns of biological community development at nascent deep-sea hydrothermal vents (950’N, East Pacific Rise). Deep. Res. Part II Top. Stud. Oceanogr. $45,465-515$.

Sheader, M., Van Dover, C.L., 2007. Temporal and spatial variation in the reproductive ecology of the vent-endemic amphipod Ventiella sulfuris in the eastern Pacific. Mar. Ecol. Prog. Ser. 331, 181-194.

Shillito, B., Le Bris, N., Hourdez, S., Ravaux, J., Cottin, D., Caprais, J.-C., Jollivet, D., Gaill, F., 2006. Temperature resistance studies on the deep-sea vent shrimp Mirocaris fortunata. J. Exp. Biol. 209, 945-955. doi:10.1242/jeb.02102

Smith, F., Brown, A., Mestre, N.C., Reed, A.J., Thatje, S., 2013. Thermal adaptations in deepsea hydrothermal vent and shallow-water shrimp. Deep Sea Res. Part II Top. Stud. Oceanogr. 92, 234-239. doi:10.1016/j.dsr2.2012.12.003 
Tivey, M.K., Bradley, A.M., Joyce, T.M., Kadko, D., 2002. Insights into tide-related variability at seafloor hydrothermal vents from time-series temperature measurements. Earth Planet. Sci. Lett. 202, 693-707.

Tunnicliffe, V., 1990. Observations on the effects of sampling on hydrothermal vent habitat and fauna of Axial Seamount, Juan de Fuca Ridge. J. Geophys. Res. Solid Earth 95, $12961-12966$.

Tunnicliffe, V., 1991. The biology of hydrothermal vents - ecology and evolution. Oceanogr. Mar. Biol. 29, 319-407.

Tunnicliffe, V., Kim Juniper, S., 1990. Dynamic character of the hydrothermal vent habitat and the nature of sulphide chimney fauna. Prog. Oceanogr. 24, 1-13. doi:10.1016/00796611(90)90015-T

Tunnicliffe, V., Tyler, J., Dower, J.F., 2013. Population ecology of the tonguefish Symphurus thermophilus(Pisces; Pleuronectiformes; Cynoglossidae) at sulphur-rich hydrothermal vents on volcanoes of the northern Mariana Arc. Deep Sea Res. Part II Top. Stud. Oceanogr. 92, 172-182.

Vickery, R., Hollowell, K., Hughes, M., 2012. Why have long antennae? Exploring the function of antennal contact in snapping shrimp. Mar. Freshw. Behav. Physiol. 45, 161176. doi:10.1080/10236244.2012.699644

Vuillemin, R., Le Roux, D., Dorval, P., Bucas, K., Sudreau, J.P., Hamon, M., Le Gall, C., Sarradin, P.M., 2009. CHEMINI: A new in situ CHEmical MINIaturized analyzer. Deep Sea Res. Part I Oceanogr. Res. Pap. 56, 1391-1399. 
White, S.N., Chave, A.D., Reynolds, G.T., 2002. Investigations of ambient light emission at deep-sea hydrothermal vents. J. Geophys. Res. Solid Earth 107 (B1) Art. no 2001.

Williams, A.B. 1988. New marine decapod crustaceans from waters influenced by hydrothermal discharge, brine, and hydrocarbon seepage. Fishery Bulletin, 86, 263-287. 
Figure 1. Study site. Location of the Lucky Strike vent field on the Mid-Atlantic Ridge (MAR). The insert shows a selection of site locations within the vent field. The Eiffel Tower active edifice is located south-east of the lava lake, at a depth of $1700 \mathrm{~m}$.

Figure 2. Camera field of view (upper panel) and in situ spatial distribution of Mirocaris fortunata (lower panel). Upper panel: Area filmed by the TEMPO camera at the base of the active Eiffel Tower edifice (Lucky Strike, MAR) from July 2011 to April 2012. The center of the image is occupied by a tripod holding the temperature and oxygen probe. The dark green plate (A) located on the left side of the probe provided the scale $(3.5 \mathrm{~cm}$ width $)$ used to estimate the field of view surface area. B depicts a crab Segonzacia mesatlantica. The M. fortunata shrimp are visible in the mussel assemblage (white arrows, C). Lower panel: mean abundance of Mirocaris fortunata (color code from 0 to 35 individuals) in each grid cell of the study area over the 9 monthly observation sessions using the TEMPO module on Eiffel Tower (Lucky Strike, MAR). BM: Bacterial Mat, BS: Bare Substratum, M: Mussel bed, P: Probe, A: Anhydrite, An: Anemones, NI: Not Identified. The black arrow shows the location and direction of the fluid flux. The image was treated as a two dimension surface.

Figure 3. Temperature, dissolved oxygen as well as Mirocaris fortunata abundance. Evolution of temperature (black line) and dissolved oxygen (gray line) as measured by the probe in the field of view (see Fig. 2) of the TEMPO module at the base of the active Eiffel Tower edifice (Lucky Strike, MAR) from July 2011 to July 2012 (A) and in January 2012 (B). Global densities of the shrimp Mirocaris fortunata (C) from July 2011 to April 2012 are indicated. 
Figure 4. Substrata occupancy. Average monthly percentage of Mirocaris fortunata and Segonzacia mesatlantica by type of substratum between July 2011 and March 2012 on the Eiffel Tower edifice (Lucky Strike, MAR).

Figure 5. Spatial distribution of Mirocaris fortunata in the classic tank. Diagram showing the average abundance distribution of Mirocaris fortunata in the atmospheric pressure tank before, during and after feeding time. HS: Heat Source, B: Bubbler, FZ: Feeding Zone. The three concentric zones around each element represent a distance of $5 \mathrm{~cm}(0-5 \mathrm{~cm}, 5-10 \mathrm{~cm}$ and $10-15 \mathrm{~cm})$. 


\section{Tables}

Table 1. Sampling protocol for in situ observations on the Eiffel Tower edifice (Lucky Strike vent field, Mid-Atlantic Ridge) using the TEMPO ecological module, and ex situ observations at the Océanopolis aquarium in Brest (France). AP tank: tank at atmospheric pressure, Abyssbox at in situ pressure (18 bars).

\begin{tabular}{|c|c|c|c|c|}
\hline \multirow[b]{3}{*}{ Period } & \multirow{2}{*}{\multicolumn{2}{|c|}{$\begin{array}{c}\text { In situ (TEMPO) } \\
\text { At } 1700 \mathrm{~m} \text { depth on the MAR }\end{array}$}} & \multicolumn{2}{|c|}{ Ex situ (Océanopolis) } \\
\hline & & & Tank at AP & Abyssbox at 18 bars \\
\hline & $\begin{array}{l}\text { July 2011- } \\
\text { March } 2012\end{array}$ & January 2012 & April - June 2013 & April - June 2013 \\
\hline Sampling interval & $\begin{array}{l}\text { One week per } \\
\text { month }\end{array}$ & Every day & Once a week & Once a week \\
\hline Observations & $\begin{array}{c}4 \times 2 \text { min. per } \\
\text { day }\end{array}$ & $\begin{array}{c}4 \times 2 \text { min. per } \\
\text { day }\end{array}$ & 5 min. video & $\begin{array}{l}1 \text { hour observation: } \\
4 \times 5 \text { min. notes }\end{array}$ \\
\hline
\end{tabular}

Table 2. Ethological information on Mirocaris fortunata and Segonzacia mesatlantica extracted from the video data.

Intra-specific interactions

Inter-specific interactions

Organisms' activity

Observations
Isolated individuals

Aggregated individuals

Contacts among shrimp or crabs

Contacts between shrimp and crabs

Predation

Mussel closing

Shrimp escape

(-) no displacement

(+) displacement $<$ body length

$(++)$ displacement $>$ body length

Reproduction

Mating

Molting

Aggressive behaviour

Table 3. Fluid flow velocity data calculated from the video sequences recorded by the TEMPO observatory module in a Bathymodiolus azoricus mussel assemblage at the base of the Eiffel Tower 
edifice (Lucky Strike vent field, Mid-Atlantic Ridge). Each velocity value results from the average of three replicates.

$\begin{array}{llccccc}\text { Year } & \text { Month } & \begin{array}{c}\text { \# video } \\ \text { sequence }\end{array} & \begin{array}{c}\text { Average } \\ (\mathbf{c m} / \mathbf{s})\end{array} & \begin{array}{c}\text { Stdev } \\ (\mathbf{c m} / \mathbf{s})\end{array} & \begin{array}{c}\text { Min } \\ (\mathbf{c m} / \mathbf{s})\end{array} & \begin{array}{c}\text { Max } \\ (\mathbf{c m} / \mathbf{s})\end{array} \\ 2012 & \text { July } & 25 & 8.49 & 2.59 & 1.92 & 13.05 \\ & \text { August } & 25 & 8.81 & 1.94 & 4.86 & 13.07 \\ & \text { September } & 28 & 8.71 & 1.79 & 4.73 & 12.13 \\ & \text { October } & 25 & 7.24 & 2.13 & 3.39 & 11.09 \\ & \text { November } & 26 & 7.74 & 2.12 & 4.05 & 13.81 \\ & \text { December } & 26 & 7.22 & 2.60 & 4.44 & 15.40 \\ & \text { January } & 113 & 7.80 & 1.98 & 3.94 & 12.76 \\ & \text { February } & 26 & 9.13 & 1.92 & 5.58 & 12.63 \\ & \text { March } & 26 & 7.69 & 2.24 & 5.08 & 13.86\end{array}$

Table 4. Number of interspecific interactions between Mirocaris fortunata and Segonzacia mesatlantica in the discontinuous and continuous datasets.

\begin{tabular}{lcccc} 
& \multicolumn{2}{c}{ Discontinuous } & \multicolumn{2}{c}{ Continuous } \\
& Number & Mean per sequence & Number & Mean per sequence \\
Contacts & 242 & 1.04 & 167 & 1.48 \\
Escapes & 573 & 2.46 & 387 & 3.42 \\
Crab attacks & 31 & 0.13 & 10 & 0.09
\end{tabular}


Table 5. Two-way ANOVA on Mirocaris fortunata abundance at the proximity of the feeding zone. $* *$ significant $\mathrm{p}$-value $<0.01$

\begin{tabular}{lcc} 
& \multicolumn{2}{c}{$\begin{array}{c}\text { Abundance of } M \text {. fortunata in } \\
\text { the proximity of the feeding } \\
\text { zone }\end{array}$} \\
Factors & Fisher F & P-value \\
Minute & 4.282 & $0.004^{* *}$ \\
Phase & 123.213 & $0.001^{* *}$ \\
Minute $\cap$ Phase & 5.415 & $0.001^{* *}$
\end{tabular}

Table 6. Mean Abundance and percentage (between brackets) of the two crustacean species on each substratum-element in the Abyssbox during the observation period. The animals could also be swimming or not be visible to the observer.

\begin{tabular}{|c|c|c|c|c|c|c|c|}
\hline & Foam & Cord & $\underset{\text { grid }}{\text { upper }}$ & $\begin{array}{l}\text { Llower } \\
\text { grid }\end{array}$ & Bottom & Swimming & $\begin{array}{c}\text { Not } \\
\text { visible }\end{array}$ \\
\hline M. fortunata & $6(50)$ & $\begin{array}{c}0.8 \\
(6.7)\end{array}$ & $1.6(13.3)$ & $0(0)$ & $\begin{array}{c}2.3 \\
(19.2)\end{array}$ & $0.4(3.3)$ & $0.9(7.5)$ \\
\hline $\begin{array}{c}S . \\
\text { mesatlantica }\end{array}$ & $\begin{array}{l}1.5 \\
(30)\end{array}$ & $0(0)$ & $2.3(46)$ & $0.3(6)$ & $0.6(12)$ & $0(0)$ & $0.3(6)$ \\
\hline
\end{tabular}

Table 7. Summary of Mirocaris fortunata shrimp activity in situ (at 1700m depth) and ex situ at Océanopolis. AP tank: tank at atmospheric pressure, Abyssbox at in situ pressure (18 bars).

In situ

Ex situ (AP tank)

Ex situ (Abyssbox)

Mean total
abundance
145
23
12

Mean abundance of
active shrimp
140
7
7

$\%$ active shrimp
$\begin{aligned} & 96 \% \\ & 30 \% \\ & 58 \%\end{aligned}$
$\%$ active shrimp during feeding Not observed $69 \%$ $77 \%$




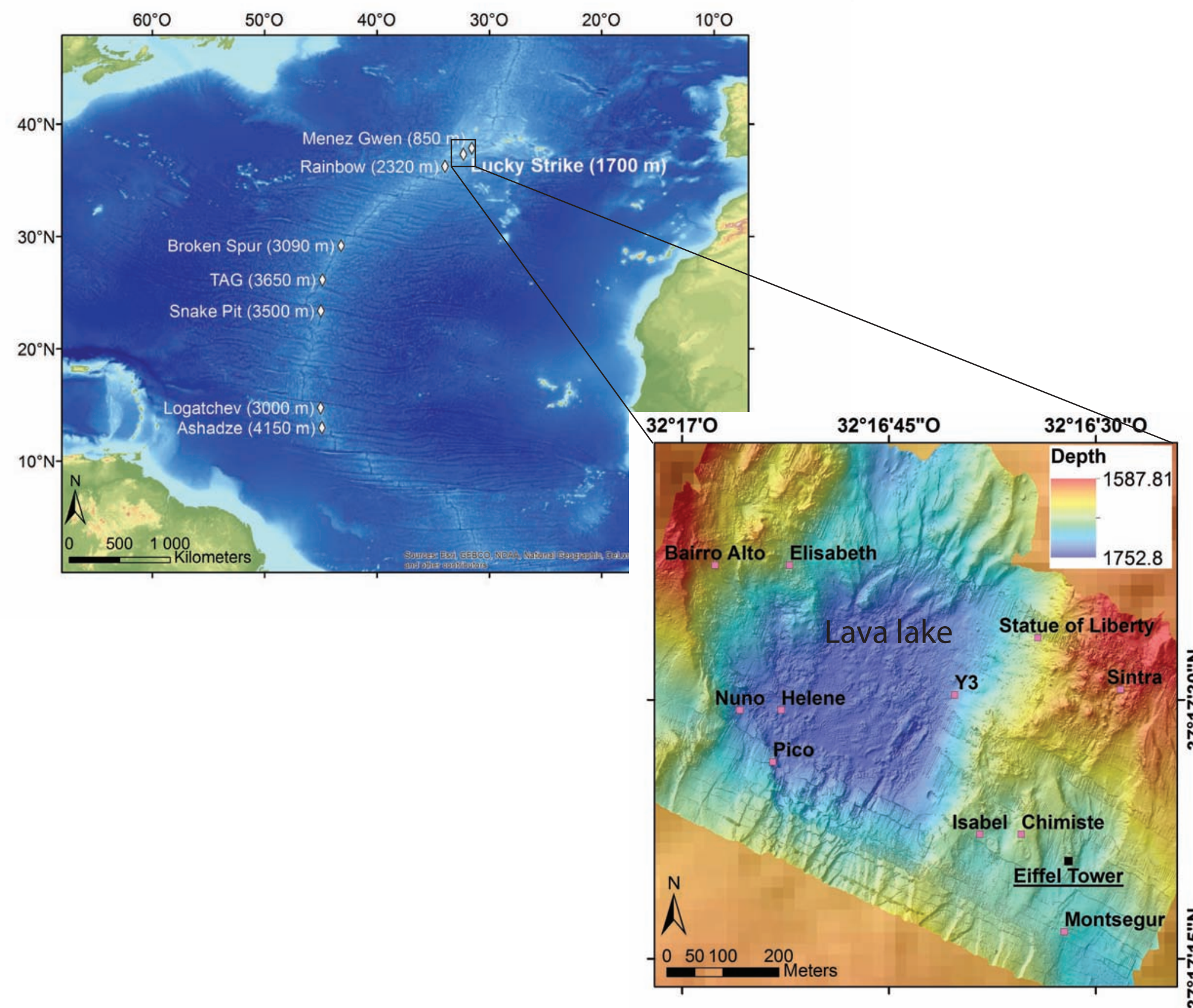



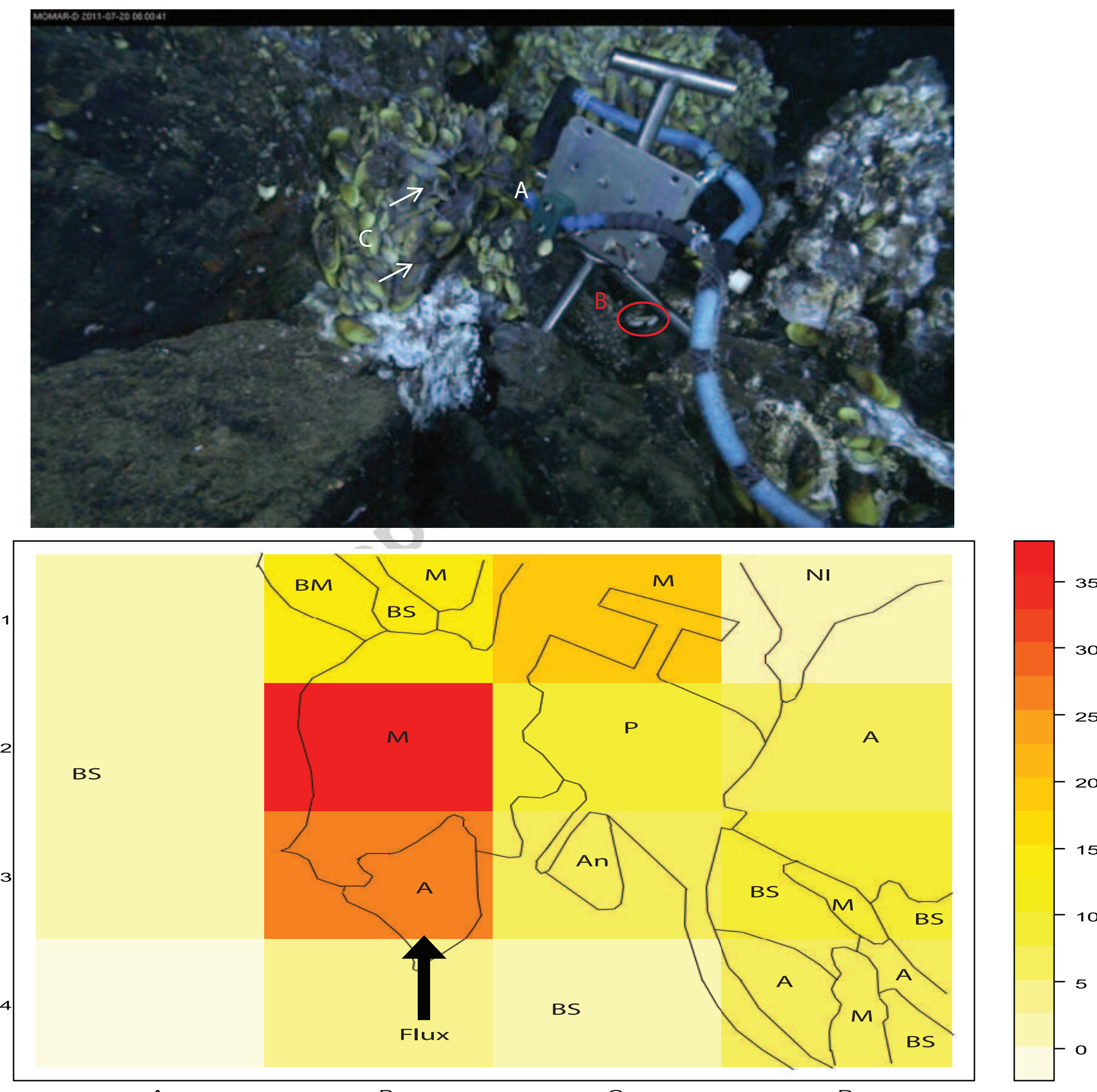


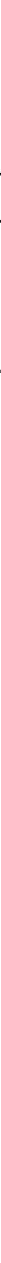


Mirocaris fortunata

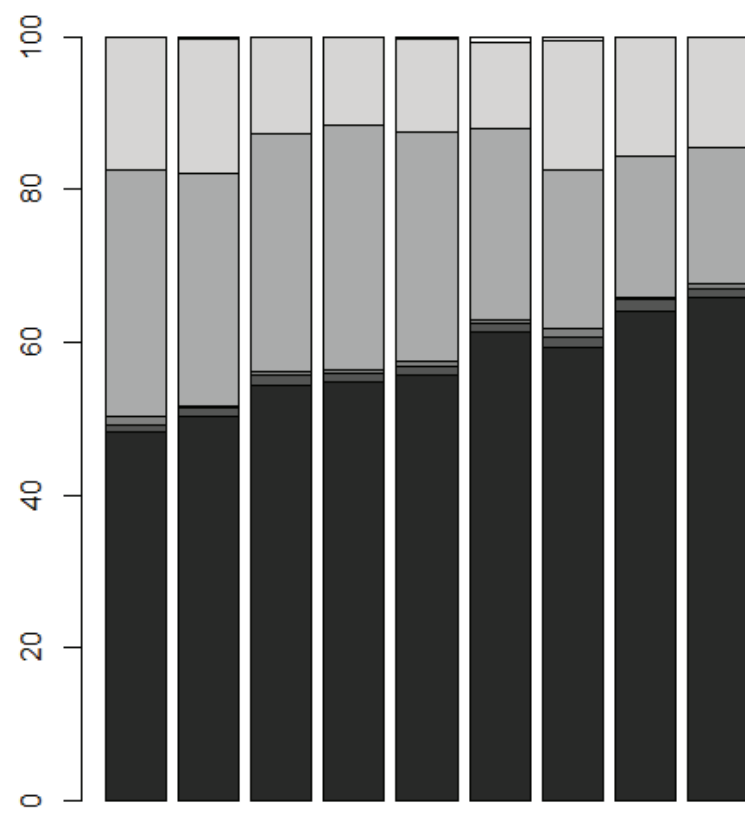

Jul Aug Sep Oct Nov Dec Jan Feb Mar
Segonzacia mesatlantica

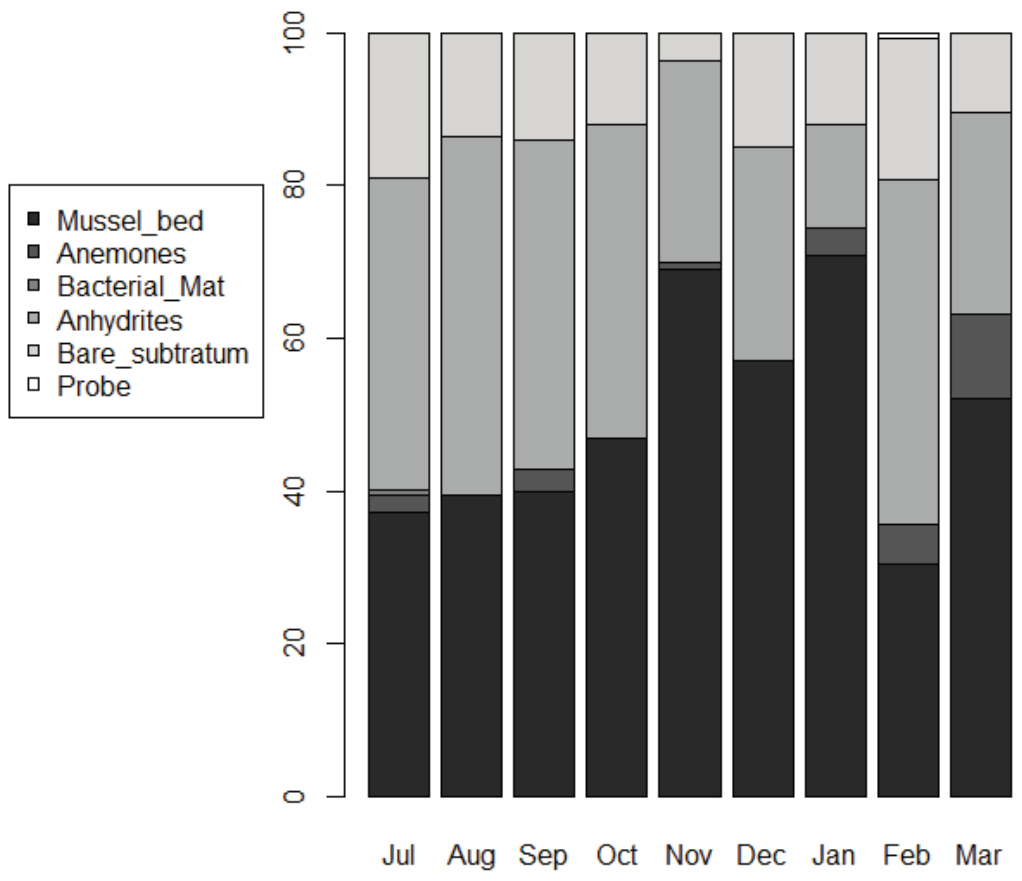


Before feeding

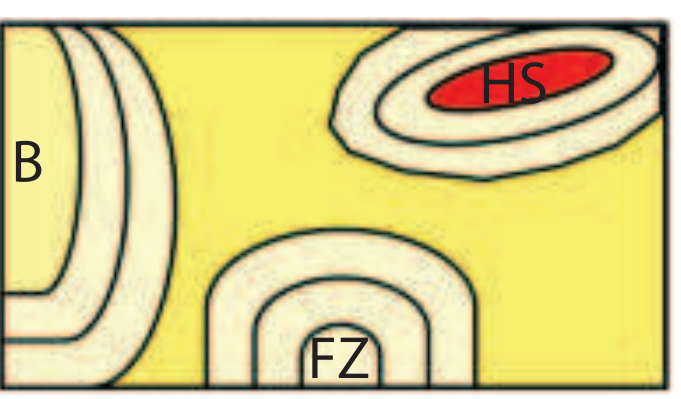

0
During feeding

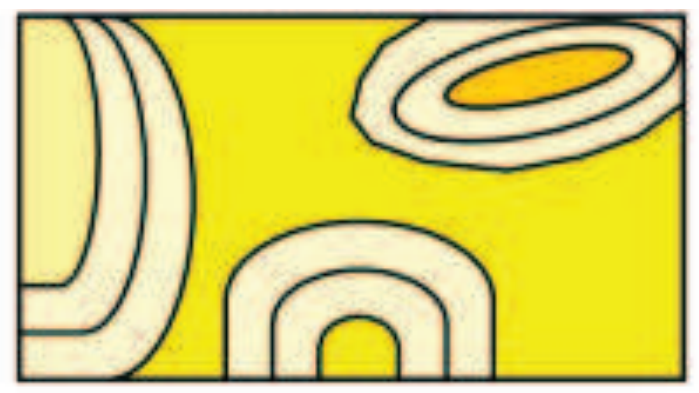

9
$1 \mathrm{~h}$ after feeding

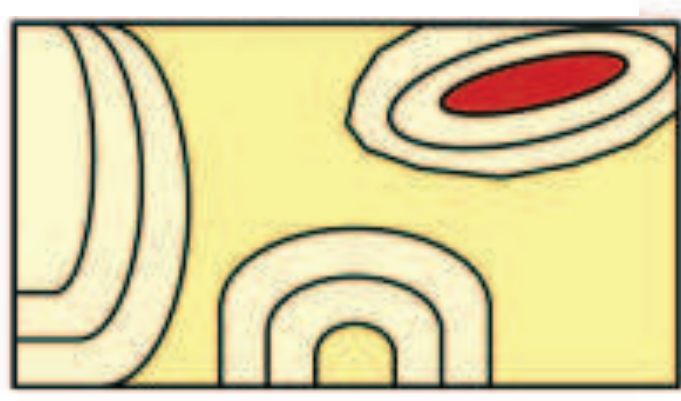

12

Mirocaris fortunata density (no of individuals) 